\title{
Level of physical activity in college students
}

\section{Nível de atividade física em estudantes universitários}

\author{
Elias Benício de Luna Filho1, Fábio Thiago Maciel da Silva², Amilton da Cruz Santos ${ }^{2,3}$, Leone Severino do Nascimento ${ }^{2,3}$, \\ Aline Nóbrega Rabay², Filipe Fernandes Oliveira Dantas 2,3, Anna Myrna Jaguaribe de Lima ${ }^{4}$, \\ Maria do Socorro Brasileiro-Santos ${ }^{2,3}$
}

\begin{abstract}
Introduction: Regular practice of physical activity is important to prevent and treat psychobiological dysfunctions and improve the quality of life. Insufficient levels of exercise have been considered a risk factor for diseases, mainly cardiovascular disorders. The evidences about the levels of physical activity in college students are inconsistent, especially in physical education undergraduate programs. Objective: The aim of this study was to assess the level of physical activity in Physical Education college students of the Universidade Federal da Paraíba, considering gender, undergraduate program (degree or bachelor) and term time. Method: The study design is transversal, and 159 subjects answered the International Physical Activity Questionnaire (IPAQ), short version. Results: Most of the college students were classified as active and very actives $(77.4 \%)$ and, only $22.7 \%$ were insufficiently actives. It was observed a significant association between the level of physical activity and the term time $(p=0.001)$, with a linear and progressive trend to towards an increase in the number of inactive/insufficiently active students. There was not significant association $(p=0.088)$ between the level of physical activity and the first or second half of the undergraduate program. College's Bachelor students of were more active than college's Licentiate students, however, without significant association $(p=0.181)$. In the difference between genders, women have higher levels of physical activity than men, but without significant association $(p=0.797)$. Conclusion: The results show that students of physical education present appropriate levels of physical activity and students of the last term time are less active than first term time students.
\end{abstract}

Keywords: Motor Activity; Physical exercise; Students; Young.

\section{RESUMO}

Introdução: A prática regular de atividade física é importante por prevenir e tratar disfunções psicobiológicos e melhorar a qualidade de vida. Níveis insuficientes de atividade física têm demonstrado ser fator de risco para doenças, principalmente as cardiovasculares. Achados sobre níveis de atividade física entre universitários são inconsistentes, especificamente, para o curso de educação física. Objetivo: Avaliar o nível de atividade física em universitários de Educação Física da Universidade Federal da Paraíba, considerando sexo, curso (Licenciatura ou Bacharelado) e período do curso. Método: O delineamento do estudo foi transversal, com amostra de 159 sujeitos que responderam ao Questionário Internacional de Atividade Física (IPAQ), versão curta. Resultados: A maioria dos universitários foi classificada como ativos ou muito ativos $(77,4 \%)$ e, apenas $22,7 \%$, como insuficientemente ativos. Observou-se associação significativa entre o nível de atividade física e o período do curso $(p=0,001)$ sendo encontrada tendência linear e progressiva no aumento do número de estudantes inativos/insuficientemente ativos. Ao analisar o nível de atividade física e a primeira metade ou segunda metade do curso não houve associação significativa $(p=0,088)$. Os estudantes do curso de Bacharelado se apresentaram mais ativos que os da Licenciatura, porém, sem associação significativa $(p=0,181)$. Na comparação entre sexos, as mulheres apresentaram maiores níveis de atividade física que os homens, mas sem associação significante $(p=0,797)$. Conclusão: Os resultados indicam que os universitários de educação física apresentam níveis adequados de atividade física e que, estudantes dos últimos períodos do curso são menos ativos que os estudantes iniciantes.

Palavras-chave: Atividade motora; Exercício físico; Estudantes; Jovens;

\footnotetext{
Corresponding Author: Maria do Socorro Brasileiro-Santos. Universidade Federal da Paraíba, Laboratório de Estudos do Treinamento Físico Aplicado à Saúde do Departamento de Educação Física. Cidade Universitária - João Pessoa - PB - Brazil. Zip Code - 58051-900 Phone/Fax: 55-83 3216 7212; Email: sbrasileiro@pq.cnpq.br; sbrasileiro@yahoo.com.br

2 Physical Training Study Laboratory Applied to Health of Physical Education Departament of UFPB, João Pessoa (PB), Brazil; ${ }^{3}$ Associate Post-Graduate Program in Physical Education UPE-UFPB, João Pessoa (PB), Brazil.
}

Full list of author information is available at the end of the article.

Financial support: The study did not receive financial support.

Submission date 28 June 2015; Acceptance date 18 September 2015; Online publication date 29 September 2015 


\section{INTRODUCTION}

Physical activity has been studied and disseminated as a fundamental policy for improving the quality of life and decreasing risk of chronic diseases in different population groups. ${ }^{(1)}$ There are several types and intensities of physical activities that bring health benefits to who its practitioners, especially for those who add up two and half hours per week or 30 minutes a day, five days a week. ${ }^{(2)}$ There is good evidence that physical activities can be carried out by those people who have little time in episodes of 10 minutes continuously throughout the day and should add a minimum of 30 minutes daily, five days a week, making a total of 150 minutes per week activities. ${ }^{(3)}$

According to WHO report, the practice of physical activity decreases with increasing age, especially during adolescence and, worldwide, physical activity and physical education are declining in schools, especially among the group of girls and women. ${ }^{(4)}$ The absence of physical activity or indices considered lower than expected for the adult population would be $17 \%$ and that between $31 \%$ and $51 \%$ of those who practice physical activity do so insufficiently, not reaching 150 minutes recommended weekly. ${ }^{(4)}$ In a study conducted in sixteen state capitals, Joao Pessoa was the capital with the highest number of individuals classified as insufficiently active, with about $54.5 \%$ regardless of age. ${ }^{(5)}$

An important group of the population that has been poorly studied over time is to college students, mainly from the area of Physical Education. Silva et al. ${ }^{(6)}$ indicate that about $92 \%$ of physical education course students have adequate levels of physical activity. The study of Bara Filho et al. ${ }^{(7)}$ showed that the higher the grade level, the lower the level of activity among students, thus suggesting that over time, students tend to decrease physical activity. However, Silva et al. ${ }^{(6)}$ found that the pattern of physical activity remains constant during the course of physical education and that male students are more active than females.

Despite these results, the lack of studies does not precise the prevalence of physical activity levels in physical education students. In addition, there are few information in the literature regarding how gender and over the undergraduate course are associated with this prevalence as well, there are no studies that have investigated the possible association between the curriculum (Graduate Degree) and the physical activity levels of these students. Thus, the aim of the study was to evaluate the levels of physical activity in undergraduate Physics Education Course of the Universidade Federal da Paraiba, as well as verify the association between physical activity levels with gender, course period (1st to $8^{\circ}$ ) and the curriculum (Graduate Degree).

\section{METHOD}

\section{Characterization of the sample and study}

The study is characterized as a transversal and primary data. The sample consisted of 159 university students (121 men and 39 women) between the 1 st and the 8 th period of Bachelor and Degree courses in Physical Education of the Universidade Federal da Paraiba.

To sample composition was made the sum of the number of students in the program, and for each period was verified the number of students. Since then it selected a compulsory subject of each physical education course period that makes up the current curriculum. Considering the ratio of students per period, it used to WinPepi program, version 3.5, to randomly select the students who respond to the questionnaires. The final sample size was defined by convenience.

To attend the sample, the students should be the from the Physical Education course, to be among the 1st to the 8th period of the course, and be properly enrolled in a compulsory subject during his semester, be aged between 18 and 30 years and may be of either gender. Students were excluded if they had any pre-existing condition that could interfere with the results of the research, cognitive impairment or who refused to answer the questionnaires.

\section{Classification Level of Physical Activity}

To classificate the level of physical activity it was used the International Physical Activity Questionnaire (IPAQ), short version. The questionnaire questions are related to activities undertaken in the last week prior to application. The IPAQ questionnaire was administered by a single researcher, at the place and time of the lessons. The subjects received the same verbal orientation, even not communicating with each other during the time they were answering the questionnaire. Any questions should be clarified at the time of filling the application responsible for the IPAQ. The questionnaire was carried out according to the availability of each period, the end of the classes, and their fill performed voluntary. There was no time limit for completing the questionnaire.

The IPAQ questions seek to provide information on the frequency (days/week) and duration (minutes/day) in the execution of hiking and daily activities that require physical efforts of moderate and intense. For categorization of habitual physical activity was considered four categories: Very active, active, irregularly active or sedentary/inactive according to the consensus of CELAFISC and the Centers for Disease Control (CDC) 2002 described by Matsudo et al(8)

- Inactive: does not perform any physical activity for at least 10 continuous minutes during the week;

- Insufficiently active: consists of classifying the individuals who practice physical activities for at least 10 continuous minutes per week, but insufficiently to be classified as active;

- Active: one that complies with the following recommendations:

a) vigorous physical activity: $\geq 3$ days/week and $\geq 20$ minutes/session;

b) moderate or walk: $\geq 5$ days/week and $\geq$ 30 minutes/session; 
c) any activity added: $\geq 5$ days/week and $\geq 150 \mathrm{~min} /$ week (walking + moderate + vigorous).

- Very active: one that complies with the following recommendations:

a) vigorous: $\geq 5$ days/week and $\geq 30 \mathrm{~min} /$ session or

b) vigorously $\geq 3$ days/week and $20 \geq \mathrm{min} /$ Session + walk or moderate, and $\geq 5$ days/week and $\geq 30 \mathrm{~min} /$ session.

\section{Statistical analysis}

We used the Statistical Package for Social Sciences (SPSS) version 18.0. Descriptive statistics were used to observe the percentage distribution for the categories proposed by the instrument and the distribution of a course period of physical education and gender difference. Then, we used the chi-square test for linear trend for evaluation of association and distribution ratios in the variables. The significance level was set at $p<0.05$.

\section{Ethical Considerations}

This research is according with the Resolution 466/12 and was approved by the Research Ethics Committee of the Health Sciences Center of the Universidade Federal da Paraíba, protocol 0503/13; CAAE 20775013.7.0000.5088. Participants were informed about the objectives, study procedures, independent participation in research, are guaranteed anonymity. Then they read and signed the free and informed consent.

\section{RESULTS}

Table 1 shows the anthropometric characteristics of physical education students, divided by the course (degree and bachelor's degree) and by gender.

Figure 1 shows the prevalence of physical activity levels of undergraduate students in physical education. We opted for the reorganization of physical activity level data for presentation in three categories in which the subjects classified as "inactive" were added to the "insufficiently active" so that the data were better expressed.
In Figure 2 shows the prevalence of activity level among students of Degree Courses and Bachelor courses of Physical Education. Students of the Bachelor Physical Education course, presented a higher percentage of subjects classified as active and very active, making a total of (81.3\%). However, there was no significant association between mode of travel and the level of physical activity $(p=0.181)$.

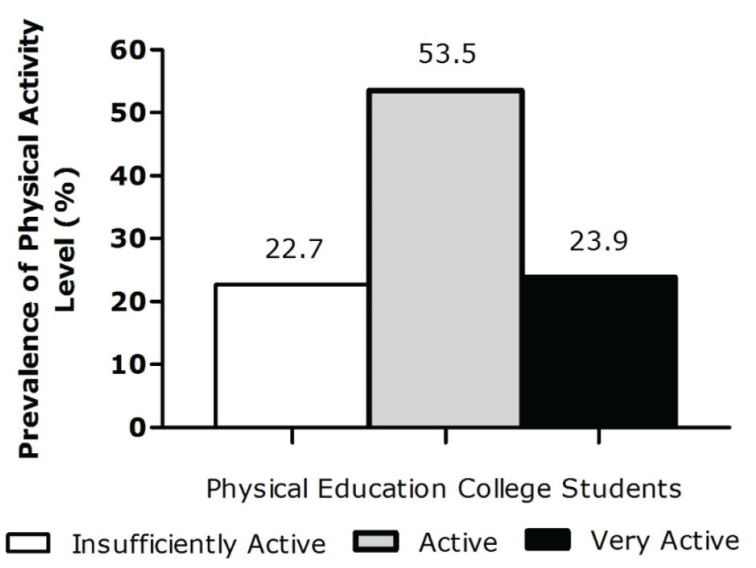

Figure 1. Prevalence of physical activity in students of Physical education course from Universidade Federal da Paraíba.

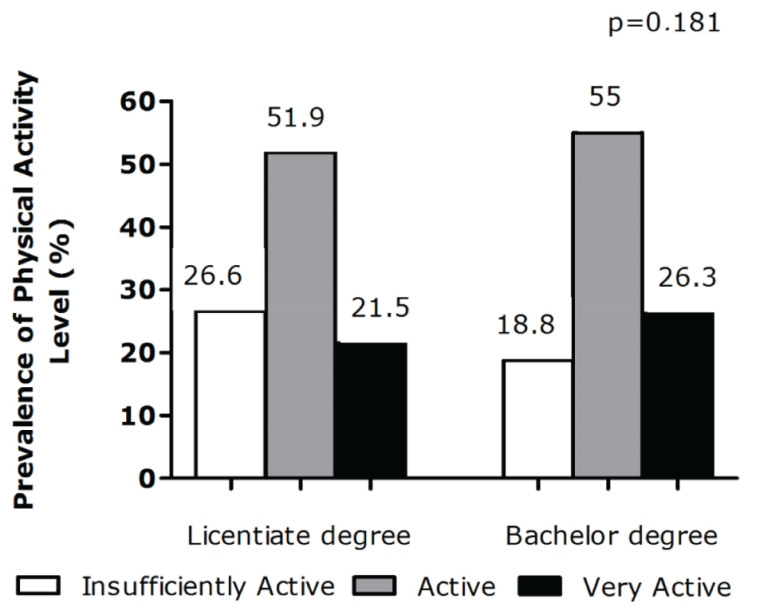

Figure 2. Prevalence of physical activity among students of Degree Courses and Bachelor of Physical Education of the Universidade Federal Paraíba.

Table 1. Anthropometric characteristics of students degree and bachelor's degree of Physical Education of the Universidade Federal da Paraíba.

\begin{tabular}{|c|c|c|c|c|}
\hline \multirow[b]{2}{*}{ Variable } & \multicolumn{2}{|c|}{ Degree $(n=79)$} & \multicolumn{2}{|c|}{ Bachelor's degree $(n=80)$} \\
\hline & $\begin{array}{c}\text { Male } \\
(n=60)\end{array}$ & $\begin{array}{c}\text { Female } \\
(n=19)\end{array}$ & $\begin{array}{c}\text { Male } \\
(n=61)\end{array}$ & $\begin{array}{c}\text { Female } \\
(n=19)\end{array}$ \\
\hline Age (years) & $21.8 \pm 2.9$ & $20.9 \pm 2.5$ & $22.0 \pm 2.7$ & $21.1 \pm 2.0$ \\
\hline Body mass (Kg) & $75.2 \pm 12.2$ & $55.0 \pm 6.4$ & $73.9 \pm 9.5$ & $56.3 \pm 8.9$ \\
\hline Height (m) & $1.76 \pm 0.1$ & $1.62 \pm 0.1$ & $1.75 \pm 0.1$ & $1.63 \pm 0.1$ \\
\hline BMI $\left(\mathrm{Kg} / \mathrm{m}^{2}\right)$ & $24 \pm 3.3$ & $20.9 \pm 2.2$ & $23.9 \pm 2.3$ & $21.3 \pm 2.4$ \\
\hline
\end{tabular}

$\mathrm{BMI}=$ body mass index; $\mathrm{Kg}=$ kilogram; $\mathrm{m}=$ meters. 
The physical activity level of percentage for the physical education students at different periods of the course (Figure 3) show that, during the course was observed a linear and progressive trend in the increase in the number of inactive students / insufficiently active. In contrast, there was a progressive and significant decrease in the number of very active students. Thus there was a statistically significant association between the periods and the physical activity levels $(p=0.001)$.

Table 2 presents the individuals in the first and second half of a degree in physical education and the prevalence level of physical activity. For this analysis, the variable level of physical activity was categorized into two groups: low level of physical activity (inactive/insufficiently active) and high levels of physical activity (active/very active). Such categorization was carried out in order to apply Pearson's chi-square test, analyze associations between the dependent and independent variables and calculate the extent of prevalence ratio. It is observed that students in the first half of the course have a prevalence of $42.7 \%$ lesser of insufficient physical activity, when compared to students in the second half of the course.

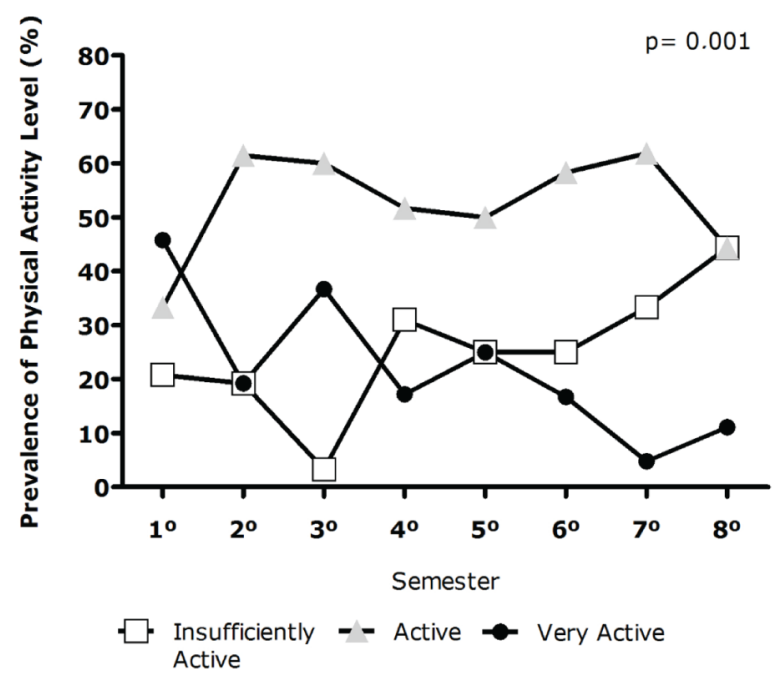

Figure 3. Prevalence of physical activity level of students from 1st to 8th period of Physical Education Course (Degree and Bachelor) of the Universidade Federal da Paraíba.
Nevertheless, the association between the current phase with the level of physical activity was the significance threshold.

Regarding the prevalence of physical activity level with gender, there was no significant association ( $p=0.797)$. It was decided to do not separate the Degree from the Bachelor courses for the small number of students, especially girls (less than 20 in both courses). In both courses the women had higher levels of physical activity $(57.9 \%)$ are classified as active, when compared to men (52\%). In the classification of insufficiently active observe that men had a higher percentage (24\%) compared to women (18.4\%). Respect to the classification of very active if there equivalence percentage compared to men (24\%) and women (23.7\%).

\section{DISCUSSION}

The results of this study indicate that most college students in Physical Education are classified as active or very active, but no significant association with the curriculum of undergraduate (Licentiate or Bachelor). However, it was observed the existence of a significant association between physical activity level and degree course period. In addition, there seems to be an associative tendency between physical activity level and the first half or second half of the course. No difference was observed between men and women.

Other studies have sought to profile the physical activity level in different courses mainly healthcare. Silva et al. ${ }^{(6)}$ found that students of Physical Education courses (90\%) and biology $(86.9 \%)$ were classified as active and very active compared to the college of Pharmacy courses (56\%) and Dentistry (61.1\%). Nevertheless, statistically significant differences were observed. Research by Rodrigues, Cheik and Mayer ${ }^{(9)}$ showed that $51.1 \%$ of students in general were active and $7.6 \%$ inactive. Studies with the same population, carried out in northeastern Brazil, Carvalho and Martins et al. ${ }^{(10)}$ found a prevalence of $28.4 \%$ of inactive, $23.6 \%$ of insufficiently active, $30.9 \%$ active and $17,1 \%$ very active.

Studies comparing the undergraduate courses in Physical Education as proposed, are still scarce. Although not statistically significant, it was observed that students of the Bachelor present more active than Licentiate, leading to the assumption that the curriculum can be positively associated

Table 2. Association between period of course and level of physical activity in students of Degree and Bachelor course of Physical Education of the Universidade Federal da Paraíba.

\begin{tabular}{|c|c|c|c|c|c|c|}
\hline \multicolumn{7}{|c|}{ Physical Activity Level } \\
\hline & \multicolumn{2}{|c|}{ Low level of PA } & \multicolumn{3}{|c|}{ High level of PA } & \multirow{2}{*}{ PR (IC 95\%) } \\
\hline & $\mathrm{n}$ & $\%$ & $\mathrm{n}$ & $\%$ & $\mathbf{p}$ & \\
\hline First Half Course & 20 & 18.3 & 89 & 81.7 & 0.088 & $\begin{array}{c}0.573 \\
(0.326-1.010)\end{array}$ \\
\hline Second Half Course & 16 & 32.0 & 34 & 68.0 & & \\
\hline
\end{tabular}

$\mathrm{PA}=$ Physical Activity; $\mathrm{PR}=$ prevalence ratio; $\mathrm{Cl}$ = confidence interval. 
with the level of physical activity of students of the Bachelor. Another explanation is that the search for the Physical Education course can be related to experiences in the field of sports or physical activity, because in most cases these same students are athletes of different sports and are seeking to specialize in this area to continue working, as technical or physical trainers, which according to the class council would Professional function with training in the bachelor's degree, which could also explain the higher physical activity rates in this group compared to the Bachelor and the general population. ${ }^{(11)}$

The results of this study identifies association between physical activity level and degree course period, plus trend for association between physical activity level and the first half or second half of the course. These results corroborate those presented by Bara Filho et al. ${ }^{(7)}$ studied college students at an early and final stage in Physical Education and also students of the master's degree in Physical Education and observed that students of education tend to be less active physically after graduation, as well as exacerbate this scenario for those who reach the master, showing that teachers and students are finding themselves in contradictory situations, indicating physical activity, but not doing. However, it noted that the present results do not show that students of the first period when approaching the end of the course will be less active (inappropriate causal relationship), but that students who are in the final phase of the course are presented less active than those who are in the early stages of the course.

Study developed by Fontes and Vianna(12), also at the Universidade Federal da Paraíba, with students from six educational centers and using the IPAQ, noted that students with higher enrollment time at the university had a significant downward trend in the intensity of physical activity performed by reducing the initially high activity rate for moderate and then moderate to low. In studies of Marcondelli, Costa and Schmitz ${ }^{(13)}$ and Pinho and Barbosa ${ }^{(14)}$, the data for the difference in periods was studied, but this research, students showed no difference in average physical activity among the different periods.

It was not identified in this study differences between men and women, although women have higher levels of physical activity. Corroborating with this finding, Hallal et al. (15) associating physical activity with other variables between two cities (Pelotas, Brazil and São Paulo, SP) are high sedentary percentages for both gender in both cities, but only in Sao Paulo with significant differences, where men are even less active than women. Some studies found no association between physical activity level and gender in the general population ${ }^{(16,17)}$ or in academic physical education. ${ }^{(18)}$ However, in other research, it found a significant association between physical activity level and gender, including with higher levels among men in different populations. ${ }^{(6,8,13,19-21)}$ Silva $^{(22)}$ addressed the same theme, university students studying physical education in northeastern Brazil and finding greater chances female being rated low levels of physical activity compared to the male.

This study has some limitations, such as the convenience of size and sample selection, however, considered the ratio between students of each period, by gender and proportion of each course (Licenciate or Bachelor); Furthermore, because it is a cross-sectional study cannot establish causality, therefore, important to note that the existence or non-existence of an association between variables should be considered carefully.

\section{CONCLUSION}

The university students evaluated in this study were classified mostly as active or very active, probably due to the profile of undergraduate courses in Physical Education involving health, performance and human movement in the educational, sports and biological sphere. In addition, it was observed that college students in Physical Education reduce the level of physical activity over the term time.

\section{ACKNOWLEDGMENT}

To Conselho Nacional de Desenvolvimento Científico e Tecnológico - CNPq (scholarship PIBIC EBLF 2012-2013). Students who participated in the study.

\section{AUTHORS CONTRIBUTION}

EBLF: We performed data collection, participated in the literature review and construction of the manuscript; ACS: Participated in the idealization of research and construction and review of the manuscript; FTMS: Participated in the construction of the manuscript, literature review and inferential analysis; LSN: Participated in the construction of the manuscript, literature review and inferential analysis; ANR: Participated in the construction of the manuscript; FFOD: Participated in the construction of the manuscript and performed the inferential analysis; AMJL: Participated in the construction and review of the manuscript; MSBS: Conceived the study, participated in the construction and review of the manuscript.

\section{COMPETING INTERESTS}

The authors declare no conflicts of interest.

\section{AUTHOR DETAILS}

${ }^{1}$ Scientific Initiation Scholarship - CNPq, Universidade Federal da Paraíba (UFPB), João Pessoa (PB), Brazil; ${ }^{4}$ Universidade Federal Rural de Pernambuco, Morphology and Animal Physiology Department, Recife (PE), Brazil.

\section{REFERENCES}

1. Guedes DP, Santos CA, Lopes CC. Estágios de Mudança de Comportamento e Prática Habitual de Atividade Física em Universitários. Rev Bras Cineantropom Desempenho Hum 2006;8(4):5-15.

2. Physical Activity Guidelines Advisory Committee. Physical Activity Guidelines Advisory Committee Report,. Washington: US Department of Health and Human Services; 2008.

3. World Health Organization. Global Recommendations on Physical Activity for Health. Switzerland 2010.

4. Organização Pan-Americana da Saúde. Doenças Crônico-Degenerativas e Obesidade: Estratégia Mundial sobre Alimentação Saudável, Atividade física e Saúde. Brasília: Organização Pan-Americana da Saúde; 2003. 
5. Instituto Nacional de Câncer. Inquérito Domiciliar sobre Comportamentos de Risco e Morbidade Referida de Doenças e Agravos Não Transmissíveis: Brasil, 15 capitais e Distrito Federal, 2002-2003. Instituto Nacional de Câncer Rio de Janeiro; 2004.

6. Silva GSF, Bergamaschine R, Rosa M, et al. Avaliação do Nível de Atividade Física de Estudantes de Graduação das Áreas Saúde/Biológica. Rev Bras Med Esporte 2007;13(1):39-42.

7. Bara Filho MG, Biesek S, Fernandes APT, et al. Comparação do Padrão de Atividade Física e Peso Corporal Pregressos e Atuais entre Graduados e Mestres em Educação Física. Rev Bras Med Esporte 2000;21(2):30-5.

8. Matsudo SM, Matsudo VR, Araújo T, et al. Nível de Atividade Física da População do Estado de São Paulo: Análise de Acordo com o Gênero, Idade, Nível Sócioeconômico, Distribuição Geográfica e de Conhecimento. Rev Bras Ciên e Mov 2002;10(4):41-50.

9. Rodrigues ESR, Cheik NC, Mayer AF. Level of Physical Activity and Smoking in Undergraduate Students. Rev Saúde Pública 2008;42(4):672-8.

10. Carvalho e Martins MC, Ricarte IF, Rocha CHL, et al. Pressão Arterial, Excesso de Peso e Nível de Atividade Física em Estudantes de Universidade Pública. Arq Bras Cardiol 2010;95(2):192-9.

11. Bielemann RM, Karine G, Azevedo MR, et al. Prática de Atividade Física no Lazer entre Acadêmicos de Educação Física e Fatores Associados. Rev Bras Ativ Fís Saúde 2007;12(3):65-72.

12. Fontes $A C D$, Vianna RPT. Prevalência e Fatores Associados ao Baixo Nível de Atividade Física entre Estudantes Universitários de uma Universidade Pública da Região Nordeste - Brasil. Rev Bras Epidemiol 2009;12(1):20-9.

13. Marcondelli P, Costa THM, Schmitz BAS. Nível de Atividade Física e Hábitos Alimentares de Universitários do 3ㅇ ao 5 Semestres da Área da Saúde. Rev Nutr 2008;21(1):39-47.
14. Pinho ST, Barbosa JG. Níveis de Prática de Atividade Física dos Acadêmicos do Curso de Educação Física da Ulbra de Porto Velho-RO. Anais da Semana Educa 2011;1(1):1-10.

15. Hallal PC, Matsudo SM, Matsudo VKR, et al. Physical Activity in Adults from Two Brazilian Areas: Similarities and Differences. Cad Saúde Pública 2005;21(2):573-80.

16. Baretta E, Baretta M, Peres KG. Nível de Atividade Física e Fatores Associados em Adultos no Município de Joaçaba, Santa Catarina, Brasil. Cad Saúde Pública 2007;23(7):1595-602.

17. Hallal PC, Victora CG, Wells JC, et al. Physical Inactivity: Prevalence and Associated Variables in Brazilian Adults. Med Sci Sports Exerc 2003;35(11):1894-900.

18. Cieslak F, Levandoski G, Góes SM, et al. Relação do Nível de Qualidade de Vida e Atividade Física em Acadêmicos de Educação Física. Fit Performan J 2007(6):357-61.

19. Azevedo MR, Araújo CL, Silva MC, et al. Tracking of Physical Activity from Adolescence to Adulthood: a Population-Based Study. Rev Saúde Pública 2007;41(1):69-75.

20. Mendes-Netto RS, da Silva CS, Costa D, et al. Nível de Atividade Física e Qualidade de Vida de Estudantes Universitários da Área de Saúde. Rev Bras Ciên Saúde 2013;10(34).

21. Palma A, Abreu RA, Cunha CA. Comportamentos de Risco e Vulnerabilidade entre Estudantes de Educação Física. Rev Bras Epidemiol 2007;10(1):11726.

22. Silva DAS. Nível de Atividade Física e Fatores Associados em Acadêmicos de Educação Física de uma Universidade Pública do Nordeste do Brasil. Rev Bras Ativ Fís Saúde 2011;16(3):193-8. 